\title{
In Different Times: Scheduling and Social Control in the Ottoman Empire, 1550 to 1650
}

\author{
KAREN BARKEY \\ Columbia University
}

Reading Ivo Andric's colorful short story, "The Vezir's Elephant," suggests a weakness in state rule consistent with a Eurocentric image of Ottoman backwardness. ${ }^{1}$ In the story, just as Bosnian peasants familiarized themselves with the habits of one Turkish official, he would be removed, transferred to another province and replaced by a new official with new whims and wishes. Throughout the sixteenth and a large part of the seventeenth centuries, a more or less firmly established rotation system was part of the Ottoman state mode of social control. Patrons and clients, and patrons among themselves remained foreign and unfamiliar. The resulting level of uncertainty in the provinces disrupted patron-client ties.

What appears as weakness may actually have been a source of strength. The rotation of officials increased the leverage of the state makers over their society. Instead of only relying on army and police coercion for social control, the Ottomans used rotation to reinforce their rule. By continually moving its officials, the Ottoman state disrupted local networks that might have become bases of opposition. With such local ties thrown off balance, officials and the populace remained focused on the center for resources and assignments of authority. In this essay, I argue that in the Ottoman empire temporal limits on positions and the scheduling of interruptions of such positions became a state resource used to exert social control.

The argument that time as a socially constructed resource can be manipulated strategically by contenders for power is not new. The different ways in which time can be used, however, has not been fully fleshed out. In the Ottoman case, time management was used to order relations within the ranks

An earlier version of this essay was prepared for the conference on "Time" at the Center for the Social Sciences, Columbia University. I would like to thank the participants, especially Harrison White, Paul Dimaggio, Kim Scheppelle, and David Gibson for their thoughtful comments. I am also grateful to Anthony W. Marx, Sevket Pamuk, and the readers who reviewed the article for this journal.

1 Andric (1992).

$0010-4175 / 96 / 3381-4542 \$ 7.50+.10$ C 1996 Society for Comparative Study of Society and History 
and with social groups, enhancing the control of the state over society. Different groups were made to live "in different times," as the scheduling of rotation varied. Interactions among groups were thus disrupted, maximizing their orientation toward the state as the grand scheduler. The creation of different schedules of rule and membership also provided the state with the ability to deal with groups and individuals along a multiplicity of dimensions.

Recently, Ronald Aminzade has requested more historically sensitive studies of "the dynamics producing different kinds of schedules, their connection to the exercise of power, and their relationship to larger processes of capitalist development and state formation." 2 This study is, then, an attempt to explore the temporal dimension of social control through the historical analysis of rule in the sixteenth- and early seventeenth-century Ottoman state. I demonstrate that state building was enhanced by the use of scheduling to control social elements and to diminish their potential for autonomous action. I examine three different social groups to show how scheduling state employment served as a chief mechanism of state control over society.

\section{CONTROL AND SEVERAL TIMES}

Time is socially constructed. Zerubavel's work admirably demonstrates the varying construction and the meanings we attach to time. He illustrates how social cycles shape the "rhythmic structure of social life" and how events that occur outside the expected time frame present problems for understanding and for regulating daily activities. Moreover, different periods in history can have different constructions of time, and different cultures can have different conceptions of time. Robert Merton's concept of "socially expected durations" refines the social construction of temporal dimensions of life. He defines this concept "as socially prescribed or collectively patterned expectations about temporal durations embedded in social structures of various kinds: for example, the length of time that individuals are institutionally permitted to occupy particular statuses (such as an office in an organization or membership in a group); the assumed probable durations of diverse kinds of relationships." 3 In Merton's view these socially expected durations are to be distinguished from actual durations and are of great consequence, since they shape the behavior of individuals, groups, organizations, and so forth. ${ }^{4}$ How these understandings of socially expected durations are shaped is important. People in specific cultures often build their understanding of time around the necessary chores and work activities in their environment. ${ }^{5}$ Bourdieu shows how, given societal needs and activities, the Kabyles of North Africa viewed time differently than western Europeans. ${ }^{6}$ Similarly, who shapes these understandings is also quite significant.

Given that time is constructed, those doing the construction-social actors,

\footnotetext{
2 Aminzade (1992:475). ${ }^{3}$ Merton (1984:265-6). ${ }^{4}$ Ibid., 266.
}

5 Thompson (1967). ${ }^{6}$ Bourdieu (1963). 
groups, and classes-can manipulate established notions and routines of how society is ordered, thereby forming new practices and habits. For example, Zerubavel provides a detailed analysis of the manner in which the revolutionaries in France altered the customary organization of time in order to reconstitute society around concepts of progress and modernity. The familiar organization of time around traditional calendars and schedules was perceived to provide the religious and aristocratic institutions of French society with power and privilege. Revolutionaries replaced these old conventions with new calendars pregnant with symbolic imagery of progress and rational development befitting a secular and egalitarian society. ${ }^{7}$ This example illustrates well the fact that social actors intentionally manipulate time to alter the socially constructed durations, expectations, and symbolism of society.

More recently, Christopher Winship has argued that we need to look at time as a scarce resource that "structures and constrains social relations." 8 Time enables and constrains action. He looks at the way in which scheduling problems and conflicts regarding time shape social relations. The manner in which schedules are built can form social groups, separate groups, restrict their interaction, and so forth. What is important to notice here is that time limits or enhances group interaction because membership takes place in time. Since people can be at only one place at one time, membership in different groups brings scheduling difficulties for any attempt at cross-membership.

Time, then, has two different attributes among others: one, it is socially constructed; and two, in this construction, it also becomes a social resource open to use and manipulation. Time as a social resource, in its conscious or unconscious manipulation by actors, defines and redefines the relations among groups and also between groups and institutions. As a social construction and as a scarce resource, time can be used to structure relations among individuals and among groups. Yet, there are a multiplicity of such constructions that can occur simultaneously. Different times exist at once. Such multiplicity might bring order to, or increase the complexity of, the social field.

Charles Tilly argues that political authorities are engaged in arranging time in at least two different ways: They preempt and arrange the time of citizens directly when they employ and conscript; and they establish "their own inescapable temporal references: clock times, calendar times, schedules of school and work, cycles of military service, and so on." With both of these tactics, states increasingly control and order the lives of their citizens. But few studies have specified how states use the temporal to assert their authority over society. And mostly these have emphasized temporal rules for governing rather than strategies in which time is negotiated with society and in which time and schedules are manipulated to increase leverage. Spelling out different temporal strategies for getting power will also help when applied to the realm of the state. Carruthers and Halliday present the importance of tempo-

\footnotetext{
7 Zerubavel (1981:ch. 3). $\quad 8$ Winship (1992). $\quad 9$ Tilly (1993:2).
} 
rality in decision making. Planning ahead, agenda setting, knowing when to act-these are all ways in which political actors can shape political results. ${ }^{10}$

My argument is about the manner in which a state can get power either by shaping or reinforcing the social structure of society around rhythms of action. I do not necessarily view state action as entirely rational: I believe that a mixture of old practices and new requirements forced systems of rule to be established. When the benefits of such systems become clear, such action is repeated. Therefore, state officials (willingly or unwillingly) ensure that certain patterns of action are chosen over others and that they institutionalize those relations perceived as beneficial to the state organization. As such, state officials secure desired social and political outcomes.

Time and power are then related in many varying ways. Different temporal orderings and different schedules can subsist at the same time, providing the opportunity for change, for reversal of policy, for negotiation. Also, to the degree that a multiplicity of these orderings exist concurrently, a certain fluidity to the system can be maintained. Time orders can be used to challenge and reverse alternative orders, making the social field more complex by adding more opportunities for forming strategies. An analysis of Ottoman temporal rule and strategies should enlighten both of these dimensions of state power.

\section{OTTOMAN IMPERIAL ROTATION: THE ARGUMENT}

The Ottoman Empire, among other strategies, used temporal terms of office, or tenure in office to shape social and political outcomes. Office holding in general has a temporal dimension that starts with appointment and terminates with dismissal or death of the officeholder. What is unusual about the Ottoman system of office holding was that it operated around varying and unsynchronized time intervals. ${ }^{11}$ The state ordered its relations with societal groups around different schedules, shaping interactions with the state as well as across the spectrum of groups, thereby influencing the broad social arena.

Time was used as a resource, an effective tool for ordering the multiple and complex relations in society. Like many other patrimonial imperial states, the Ottoman state was unable to fully permeate and control society without the help of elites. Yet control through elites ran the risk of these intermediaries gaining more power than the central state itself. Since reliance on elites was therefore risky, the Ottoman state strove to make the elites dependent on the center. As such, scheduling became one of the mechanisms by which the state could assert its power over regional elites who were running the empire on its behalf. Weber's analysis of patrimonial rulers included rotation of such elites pursued both by Frankish courts and Islamic empires. ${ }^{12}$

10 Carruthers and Halliday (1992); see also Lukes (1974).

11 Harrison White, in his book, Chains of Opportunity: System Models of Mobility in Organizations, identifies an organizational system that has the same characteristics as the Ottoman rotation system (1970:ch. 1).

12 Weber (1978:1042-3). 
As relations between different elites became complex and competitive, temporality of office was used to coordinate, stagger, and control. Rhythms of office holding developed, with officeholders operating within a certain sense of the common time but often out of synchronization with each other enough to upset attempts at autonomous social consolidation. Different groups developed different constructions of time, based on their particular schedules.

The state's control over time in office kept office holders focused on the center. As the central administration set policy for scheduled segments of office holding, individuals made special arrangements whereby such policy was bypassed. For example, given a concerted attempt on the part of the sultans to make all provincial offices rotate, an undercurrent also operated whereby temporary office holding was altered into hereditary tenure. The policy of rotation and its reversal took place simultaneously, both carried out by the state, attesting either to a certain fluidity or to some inconsistency in state decisions and rule. Multiple constructions of time therefore occurred all at once. But, I will argue that the result was to reinforce central state control.

I will show how the Ottoman state used temporal dimensions of rule to regulate the behavior of various groups in society. I will begin by providing a brief description of the Ottoman state and its policies vis-à-vis different office holders and societal groups. I will argue that, for the groups most likely to present opposition to the state, the Ottoman state makers used time to limit office holding, thereby increasing the center's leverage and defining the confines of extra-state power. Potentially powerful and contentious elements of society, such as the provincial military, the members of the judicial hierarchy, and even mercenaries, were all subjected to some sort of temporally devised rotation system.

\section{The Ottoman State}

The Ottoman state was formed out of a process of war and bargaining between frontier principalities in Anatolia. During an extended period of border skirmishes, one of the Turkish beys (commander), Osman Gazi, fought a war with Byzantium (1301) and won. Victory solidified his reputation, enabling him to incorporate neighboring principalities. Those who did not join through peaceful negotiation were incorporated through war. Ottoman geopolitical power was enhanced by religious ideology. The ideal of gaza prescribed that the realm of Islam was to be expanded through Holy War. The frontier principality expanded and slowly consolidated under the leadership of Osman, who came to be the first Ottoman ruler, starting a dynasty that was to last over 600 years. The state grew out of the House of Osman as a patrimonial household. The sultan, the head of the household, presided over the dynasty (his family), the ruling class formally enslaved to the sultan, his flock (his people), and the territory as the "dynastic patrimony." 13 "In the sultan, the state found the

13 Findley (1980). 
embodiment of its unity and its one source of legislative authority apart from Islamic law and established custom, while hereditary succession within the dynasty provided the means by which this unity and authority were perpetuated over time."14

Most European descriptions of the Ottoman state and society centered around the telling description of Oriental despotism. An all-powerful state was projected as having gained its power from the weaknesses of societal elements. For example, the notion that the ruling class was made of slaves was marveled at as the key to state power. With bondage as an extreme form of enforced obedience and dependence, authority was then ensured to the state. ${ }^{15}$

A formally enslaved ruling class was certainly remarkable, but such bondage was only one device of control. Such control also had to be exerted beyond the household of ruling slaves. Rather than a fully institutionalized system of traditional control, the Ottoman state acquired power through different forms of action and bargains with different groups. Similarly, the Ottoman government developed strategies to embrace mercenaries and bandits in order to subdue them. Again, the state acquired its strength by incorporating and making outsiders part of the Ottoman universe. In the process, time and scheduling played a crucial role in establishing control.

These diverse mechanisms of control made the Ottoman empire quite unique in its centralized control, especially during the sixteenth and seventeenth centuries. By contrast, up to the rise of absolutism, the European feudal system demonstrated a weak and decentralized system of control. There, essential domination over society was carried out by autonomous magnates and clerics ensconced in their office and lands with lifetime tenure and little incentive to respond to a state to which they were only minimally bound by contract. It is only with the development of absolutism that European states took measures to gain for themselves autonomous "sources of power" previously held by societal elites. The Ottoman state, by contrast, had acquired its own autonomous sources of power early on in the establishment of the specific compact between state and society.

The temporal aspect of Ottoman administration has not drawn the attention of many analysts of time or of academics. Historians and pamphleteers of the sixteenth and seventeenth centuries who discussed issues of office holding at length hardly mentioned rotation. Officials suffered from continually being rotated in and out of office, with periods of unemployment between postings. But those pamphleteers who wrote gallingly of the changes they observed in office-holding patterns did not mention the hardships of rotation. ${ }^{16}$ Historians

14 Ibid., 7. 15 S. Rudolph (1987).

16 It should be noted that there are no reliable statistics on the ratios of rotation and heredity for the empire. Recently only a few studies have undertaken the task of analyzing this phenomenon of Ottoman rule, although without empire-wide statistics. 
of the Ottoman empire focused more keenly on the institutions of Ottoman rule rather than on its dynamics. ${ }^{17}$ In the absence of comparisons with the Western continent, the contrast between heredity and rotation was not fully analyzed. ${ }^{18} \mathrm{As}$ a result, the movement of officials was of a secondary interest, mentioned only after the origin and the particular task of officials was scrutinized. Yet, the movement of officials was a significant factor in the maintenance of a strong Ottoman state able to manipulate groups and maintain a society mostly free of organized contention.

The establishment and the dynamics of this rotation insured that the state increased its control over those groups with the potential to develop regional affiliations as countervailing forces. By rotating officials, the state retained the power to organize and reorganize the pattern of association among groups. The system of rotation emerged from other pragmatic concerns. Too few positions for an excess of candidates required moving officials around to provide at least some employment to all. Rotation was also devised as a response to shortages of money in the administration. When the treasury was depleted, temporary hiring freed the state from having to pay all of its officials all of the time. In many ways then, rotation seems to have been a response of the state to crises within society that laid the foundation for greater control.

I analyze three different groups to show how temporal control was effected. The provincial military and administrative officials who functioned as land holders in most of Anatolia and Rumelia were rotated on a more or less regular schedule. This ensured the lack of strong patron-client relations in most of Anatolia and parts of the Balkans. Similarly, the ulema (the learned class of officials) - with the exception of the highest ranking ulema, the seyhül-Islam-were rotated in and out of positions. In the case of the kadis (the judges), rotation was carried out both to relieve oversupply and to hinder rural inter-class alliances. Such different schedules of rotation became a mechanism of control that prevented elites from permanently settling in a region. As I will discuss later, there are indications that these systems of rotation were adaptations of similar arrangements found in the ancient Near East (the iqta) and the Byzantine empire (the pronoia). The origin of such a system of rule in the Ottoman empire was, then, part traditional practice and part necessity.

By the late sixteenth and seventeenth centuries, mercenaries and bandits were another category of actors with whom the state had to deal. A by-product of state centralization, these groups became important players in rural Anatolia. As simple mercenaries, their armies were rotated in and out of work according to an irregular schedule of war. Without postings, they often turned

17 There are two exceptions to this: first, the work of Inalcik on the Ottoman legal institution and the inbuilt rotation system within it; and, second, the work of Metin Kunt on provincial elite organization and its transformation in the late sixteenth and early seventeenth century (see Inalcik 1988; Kunt 1983).

18 Barkey (1991a). 
their military skills and tools to banditry. In response, the Ottoman state struck bargains with them in order to effectively schedule confrontation for periods of relative external security and peace. This scheduling was ad hoc, a strategy rather than a firm policy or system.

The relationship with officials and bandits developed as the state expanded. To retain control, the state transformed the provincial official structure, producing a locally destabilizing dynamism which stabilized the center. Much as "a rolling stone gathers no moss," a rotating land holder or judge gathered no clients. Land holders did not become landlords, rarely developing a significant social or political relationship with the peasantry. For the judges, a different system of rotation impoverished the judge, transforming a potential alliance with the peasantry into a relation based on exploitation. The peasants remaining in place in seemingly timeless permanence, experienced many officials in one lifetime, observing them as outsiders while striving to avoid them. Bandits were alternatively embraced or crushed according to an unpredictable schedule, creating uncertainty and discord among them. In the rotation system, the Ottoman state ensured that provincial groups would remain strangers to each other, living as they did in different structures of time.

\section{The Provincial Administrators}

The provincial military class developed with the extension of a strong patrimonial center. The provincial army comprised local power holders at the time of conquest, members of the sultan's military elite and various other soldiers fighting at the frontiers of the empire. All were eager to get land assignments and fight for the expansion of the realm so as to increase their booty and land. Rotation, (also called temporary dismissal ${ }^{19}$ ) was the method by which a land holder could strive for more land. Each hoped that the next posting would be more lucrative. The bureaucrats involved in the assignment procedure used rotation to find positions for the increasing number of candidates. For the state makers more generally, rotation helped to prevent the long-term establishment of any privileged house distinct from the center.

Brief tenure in office was only possible because there was a wellestablished policy of state ownership of land. In this system-which Weber termed prebendal ${ }^{20}$ - the land did not belong to the cavalrymen or the governors but to the state, which administered it carefully. At the height of Ottoman power, about 87 percent of the land was state-owned. ${ }^{21}$ The lack of private land ownership strengthened the patrimonial household, ensuring the ruler's ability to maintain and secure his position. ${ }^{22}$ These patterns of state ownership made it possible for rotation to be secured and for heredity of land to be strictly limited. Overall, then, the system prevented the establishment of any permanent legal relation between the land holder and the land.

19 Inalcik (1995:115-6). 20 Weber (1978, II:1077-9).

21 Inalcik (1973:110). 22 Weber (1978, II:1043). 
The cavalry army, the core of the Ottoman provincial administration, consisted of prebendal land holders (ttmar holders) and their retinues. Members of the cavalry were allocated land in return for service in the provincial army. ${ }^{23}$ They were and remained servants of the state, administering, fighting, and policing for the sultans. As the state grew and the territory under its control expanded, this class of prebend holders became more differentiated, creating multiple levels of provincial control and administration. Even though the rules of tenure and the schedules of rotation were different for different ranks, the general principle of movement applied to all members of the provincial organization.

Although the tımar holders made up a class, they largely understood themselves as individuals whose fortunes were tied to a state which manipulated their tenure arrangements. To borrow a term from Karl Marx, they represented a class-in-itself. ${ }^{24}$ In terms of their own interest as a class, the tımar holders were not well positioned, as members of this group were formally linked to the state and not to other tımar holders. Individual fortunes were tied to the state, which rewarded prowess in war, dismissed, rotated, or cast some out of the system. The arrangement was successful, as the promise of rewards kept participation in war high and officials satisfied. Obedience was encouraged by the possibility that larger domains might be acquired: The more successful the warrior, the larger the domain he could get. In fact, even during periods in which they were dismissed from land holding, cavalrymen were expected to participate in campaigns, show valor and thereby hope to again be eligible for a larger demesne. Timar holders aspiring to larger domains perceived the rotation system as meritocratic rather than controlling. Consequently, records indicate many tımar holders chose rotation willingly, hoping that the next time around they would get more land. ${ }^{25}$ And as the empire grew, this expectation was often fulfilled.

How was this type of tenure established? The answer lies in a blend of history, practical need, and some learning from unintended consequences of state action. Two ancient traditions can be claimed as predecessors of the tımar tenures system. The Muslim antecedent, the iqta, went back to the tenth-century Buyids, who granted their military officers land in lieu of pay. The Buyid, the Ghaznavid, and the Seljuk empires that established the iqta originally intended the land to be revocable by state action. This principle deteriorated in the Seljuk case, where heredity set in as centralization declined. ${ }^{26}$ Another historical antecedent was the Byzantine pronoia, a land tenure arrangement with clear parallels to that of the Ottomans. Despite similarities on the military and administrative aspects of the institutions, the

23 Inalcik (1973:108).

24 I refer here to the distinction between a class-in-itself versus a class-for-itself, the latter representing the class that is able to act in its own interests.

${ }^{25}$ Howard (1987:86-87). ${ }^{26}$ Ibid., 12; Lapidus (1988:141-9). 
pronoia, however, was more of a feudal arrangement. ${ }^{27}$ While both systems bore similarities with the Ottoman tımar, they were not clear-cut precursors, especially in the temporal dimension of office holding. Land was granted but not as often revoked as it was by the Ottomans. ${ }^{28}$

The scheduling of office holders was an Ottoman device that developed in response to early state needs. From the very inception of the state, dearth of land for an increasing number of office holders became an issue that could be addressed by rotation. Harrison White's Chains of Opportunity shows how in what he terms "loose systems," few positions for many men lead to vacancies being filled faster than men can find positions. Many remain "in a limbo status." The Ottoman system had institutionalized this procedure through the principle of rotation. 29

Some of the earliest records (for example, those of 1431$)^{30}$ in the Balkans show that the timar was applied right away, transforming the positions of both the few Muslim and numerous Christian landlords in the area. The need to convert as much land as possible into state-owned, rotated prebends pushed the state to encourage Christians to give up their feudal rights and to accept the new land-holding practices of the empire. ${ }^{31}$ As part of this deal, local feudal lords who became timar holders were not forced to convert to Islam. ${ }^{32}$ As Inalc1k points out, Mehmed II's transformation of private land into state land was a deliberate attempt to increase the numbers of timar holders by increasing the supply of land available for distribution. ${ }^{33}$ Dismissal from office for one land holder provided opportunities for another. When the timar holder was finally given a sultan's order allowing him to acquire another prebend, it was his responsibility to go out and search for an adequate vacancy. ${ }^{34}$ Ottoman state makers discovered that, as a by-product of this crisis management, central control could be increased significantly with the movement of office holders.

The temporal dimension of provincial service, which can be traced to the establishment of the Ottoman Empire, altered the existing social structures. As a continuing, dynamic process of state-society negotiation, the relations between various members of the provincial community were modified. Many of the Anatolian regions conquered by the Ottoman dynasty had been occupied by hereditary owners established on the land for centuries, especially in regions belonging to the various principalities of pre-Ottoman times. Early Ottoman Sultans wanted to transform hereditary lands into rotated holdings.

The introduction of this rotation policy often pitted the state against the erstwhile hereditary landlord families. Mehmed I had to make concessions

27 Inalcik (1973) and also see Howard (1987).

28 Both these terms are not very widely used in the records attesting to the limited borrowing from these concepts.

29 White (1970:8). 30 Inalcik (1954b). 31 Inalcik (1954a:102-29).

32 Ibid., 114. 33 Inalcik (1973:109). 34 Inalcik (1995:116). 
with these local Turkish dynasties and seyhs because he was weakened during the period of interregnum. Later, Mehmed II (1451-81) and Selim I (151220 ) both made rotation an official policy of the state. Struggles ensued between members of the hereditary class and Mehmed II regarding the question of rotation. The next sultan acceding to the throne in 1481 was forced to give in, slowing the process of transformation of hereditary tenure into temporary tenure. The principle of rotation as the basis of regional power holder control was, however, important enough that the next sultan, Selim I, then reinstated it with a vengeance.

State makers engaging in negotiations with these pre-Ottoman regional elites transformed their lands into prebends, confiscated their property, and even dismantled pious foundations under which private property was disguised. ${ }^{35}$ A study of this transformation during the reign of Kanuni Sultan Süleyman (1520-66) attests to the changes. Analysis of the records of four major settlements in this period (Ankara, Bursa, Kütahya and Afyon) shows that the (vaklf) pious foundation villages had declined, while a corresponding increase of the timar lands could be seen. ${ }^{36}$

The social structure of the provinces also changed with the development of an intermediate solution between heredity and rotation, the divani-malikane. This particular arrangement evolved as a deal between local hereditary families and the state. The state and the landlord agreed to share the revenues of a particular estate, using this arrangement in areas where strong-rooted aristocracies fought state control. Where the state was stronger and local power holders less entrenched, dual ownership of this sort did not occur. ${ }^{37}$

The rotation system remained predominant in most of Anatolia and the Balkans, transforming an autonomous, and resourceful elite into servants of the state. Timar holders got their land (additional villages or sometimes new estates) from other prebend holders who went on rotation. Land therefore went in and out of an assignable pool used as a reserve. During three snapshots of one year each, 1572,1576, and 1582, an average of 45 percent of officials were rotated. ${ }^{38}$ The period during which these cavalrymen remained estateless ranged from three to seven years, after which dispossessed landholders reverted back to being commoners. Apart from fighting wars and searching for better domains, some of the land holders engaged in trade during their time on rotation and changed professions, resulting in the loss of their military status. According to Inalcık, the period of searching for adequate prebends was long, with applicants using gifts and bribes to try to shorten the ordeal. ${ }^{39}$

35 Beldiceanu-Steinherr (1979). ${ }^{36}$ Yücel (1974:673). 37 Inalcik (1995:129).

38 This figure was calculated with data retrieved from the Tımar Ruznamçe Registers 37, 46, 59, 676, 681, and 685. These registers were used at the Prime Minister's Archives in Istanbul, Turkey.

39 Inalcik (1995:116). 
The manner in which rotation affected the members of rural society strengthened the state. Landholders' temporary residence, further shortened by time on campaign, constrained local development. Court records demonstrate an acquisitive instinct consistent with the lack of long-term interest. Knowing they would be removed, landholders were interested in exploiting their temporary fief for all its worth rather quickly, scarcely giving back anything to the community. Complaints by peasants on this score abound. 40 But because of the scheduling of office, peasants did not have stable, familiar landholders to rebel against.

Crass exploitation combined with short-term tenure created tension between landholder and peasant, reducing the likelihood that they would form an alliance to rebel against the state. Court records suggest that both landholder and peasant discontent existed, but collective action remained rare. In Europe, alliances between a hereditary nobility and their peasantry were often the key to rebellions against the state. In other cases of rural rebellions, peasants allied to rebel against exploitative landlords. ${ }^{41}$ Rebellion strengthened by patron-client relations in France and other feudal regions throughout Europe remained quite a hopeless endeavor in Ottoman Turkey.

The inability of the Ottoman rural classes to ally against the state is a testimony to the state's competence in controlling the provinces to its own advantage. This was clearly the product of state ownership of land, a policy of rotation, and therefore the ability of the state makers to keep social classes in competition, distinct from each other, and in regular movement. As such, time was used as a resource to build control. Consequently, social actors behaved according to the socially expected durations which matured out of this elaborate temporal orchestration of roles.

Of even more serious consequence was the movement of higher-level military state officials, who were rotated according to a similar schedule for purposes of control. The purposeful domination of the higher ranks of the regional administration can be gleaned from the writings of the period. Most of the sources mention the hardships of these men, attributing their exploitative instincts to the precarious nature of their appointments. ${ }^{42}$ During the reign of Süleyman, the centralizing Ottoman state also took away from higher-ranking officials the power to bestow land grants. ${ }^{43}$ This inability to appoint men to fiefs reduced their capacity to develop their own patronage system. ${ }^{44}$ Both rotation and limited regional authority were certainly products of intentional, direct state action.

40 Barkey (1994). ${ }^{41}$ Brustein (1985) and Brustein and Levi (1987).

42 Koçi Bey (1972); Howard (1987); and Fleischer (1986).

43 Howard argues that the curtailing of the governor general's power to assign land did not necessarily mean centralization. However, this policy was instituted at the height of the Süleymanic era, when centralized control was the norm and the stated goal. See Inalcik (1973:114) and Barkey (1994).

44 Beldiceanu-Steinherr (1979). 
For men of high rank and prestige, such constraints imposed by the state were genuinely arduous. Provincial governors were not only hurt by short terms of office but also suffered from longer and longer rotation periods out of office. From the sixteenth to the seventeenth centuries the duration of appointment shrank considerably. In Kunt's assessment, governors remained within the same general region; but their appointments became shorter and shorter. He argues that by the 1580 s, and especially by the 1630 s, long terms (three years or more) in office were rare. Similar findings of hardship are detected for governor generals whose time spent in office was even shorter. For example, close to 60 percent of the governors general of the Ottoman provinces in the 1630s were dismissed within one year of appointment. Evliya Çelebi, in his Book of Travels, narrates how fierce rivalry and jealousy between central state viziers and top-ranking regional officials also resulted in short tenures and periods of destitution for those rotated. ${ }^{45}$ Often those appointed to the rank of grand vizier had themselves experienced the indigence of rotation but, once in power, were unwilling to do away with rotation and instead used it with a vengeance.

Differences in rotation schedules applied to governors and governors general demonstrate the intentionality of state action in the control of regional officials. Since governor generals remained consequential for central state control, they were reappointed fairly quickly and were assigned other revenues as fodder money during their periods out of office. ${ }^{46}$ The policy slowly phased out intermediaries (governors) and created competition within the ranks of the larger class of provincial elites. The consequences of such state action were dire for provincial actors: Hardship and competition proscribed burgeoning networks of patronage as well as potential intra-class alliances directed against the imperial center. The unpredictability of tenure rendered the official harsh: "Provincial governors general should be given long term appointments. Without permanent secure positions, the beys are liable to resort to injustice and when injustice prevails the people are in discomfort and the country is in distress and disorder." 47

Again by comparison, a feudal Europe with hereditary office holding presented a different provincial social structure in which networks of association between and among classes flourished, providing communications and dependencies which lay at the basis of collective action.

For all of their effectiveness at strengthening the state, these policies were not absolute. State strength often needs to be secured through flexibility, adaptation to change, and ambiguity of intent. ${ }^{48}$ Such adaptation is evident in the utilization of exceptions and in the general uncertainty attached to movement. Old families powerful enough to stand up against the Ottoman invaders kept their land under a heredity arrangement, with the proviso that they send

45 See Dankoff (1991). $\quad{ }^{46}$ Kunt (1983:70-76). $\quad{ }^{47}$ Murphey (1979:549-50).

48 White (1992) and Padgett and Ansell (1993:1259-1319). 
men to fight wars for the Ottoman army. Exceptions to the rule of rotation were made when some regional power holder was perceived to be essential to state needs. Some land holders used bribes to ensure that their sons received title to their land and remained stationary. But even such exceptions served the interests of the state with bargaining about time of office reaffirming the power of the center. And the uncertainty associated with the duration of appointment certainly enhanced state control and also became a tool as important as scheduling. The message to the dispatched official was clear: "If he behaved, he could stay longer." 49 With this ruse about the expected duration of tenure, officials were further driven into submission.

\section{The Judges}

Parallel to military provincial administrators, magistrates carried imperial justice to the provinces. Similarly empowered by the central government, these magistrates remained servants of the state but lost part of their autonomy through the process of rotation. The provincial ranks of magistrates were part of the larger literati (ulema) class. According to Inalcik, they were part of "a privileged group whose status and hierarchy was based on the level of certified knowledge in the Islamic sciences." 50 As ordinary judges, they were at the lowest ranks of an entire group of grades and offices which were led by the seyh-ül-islam, the highest ranking religious dignitary of the empire. As state envoys to the provinces, the kadis were learned bureaucrats who safeguarded the laws of Islam and the orders of the sultan while adjudicating disputes. They operated to dispense justice from a court they convoked in one of the standardized judicial districts around the empire. In their district, judges ruled according to a mix of divine and imperial authority. The kadı institution was based on the Law of God. ${ }^{51}$ The existence of an extra-sultanic source of legitimation provided this group with more autonomy at its origin than the military-administrative elite. This potential threat prompted attempts at state management. Part of this management was achieved by schedules of office holding. Rotation was used to offset the divine source of autonomy.

Unlike similar pre-Ottoman land tenure arrangements, tenure for judges had less formalized precedents in other Islamic or European societies. In fact, as the example of the kadis of Nishapur clearly demonstrates, the tradition in Islamic empires weighed in more with long-term control of a city or a region by a few ulema families. ${ }^{52}$ Also, as the Mongol conquests advanced, they allowed the local administration to remain unchanged, and therefore the institutions of Islamic learning, the local kadıs and preachers were left to flourish in their traditional communities. ${ }^{53}$ The Ottomans instead enforced the rotation of the kadıs all over the empire, often serving urban centers as varied as

49 I am grateful to Sevket Pamuk, who pointed to duration as a means of control.

so Inalcik (1988:251-75). 51 Jennings (1972:45).

52 Bulliet (1972). $\quad 53$ Lapidus (1988:278-9). 
Kayseri, Kütahya, Baghdad, and many others in one lifetime. Such rotation was arguably an independently formulated solution, ${ }^{54}$ devised to enhance state control over this potentially autonomous profession. In any case, once again, we know that different schedules were arranged early on by the state for different segments of the ilmiye (religious establishment). Uzunçarsılı argues that as a rule, a certain class of judges was appointed for one year, while others were appointed for twenty months. ${ }^{55}$

There is no doubt that rotation was perceived as a solution to the overcrowding of office in ways quite similar to that of the land-holding tenures. The language used in official reports attests to the comparability of the systems in the eyes of Ottoman bureaucrats. ${ }^{56}$ In the sixteenth century, as the position of ulema, became more accessible to outsiders who sought a religious education and expected the resulting administrative position, severe regulations were instituted for those already inside the ranks. Harsher internal measures were taken during the reign of Kanuni Sultan Süleyman (1520-66), at the same time that tighter controls were being placed on heredity and pious foundations. These actions can be compared, for example, with China, where the increase in demand for literati status directed this class to tighten the entrance requirements, making it much harder to belong.

Already in the sixteenth century most levels of the ilmiye became flooded. Authorities tried to find solutions by instituting waiting periods and increasing the number of positions available. The imperial rescript of 1597 makes this clear: "A new candidate shall not be appointed before he completes three years (of waiting) . . . The cadis [judges] of small towns shall be in possession of their post for two full years." 57 Based on the registers of the period, Inalcık points out that the duration of judgeship at a post kept decreasing, falling from three years to two and then to twenty months. By the eighteenth century the period had been reduced to eighteen months. ${ }^{58}$

Higher ranks of the ilmiye were similarly affected throughout these centuries. The major difference between the treatment of higher ranking ulema and the ordinary judges lay in the allowances made for livelihood during the time out of office. The great Mollas and Kadıaskers (chief military judges) were given generous allowances, as cash grants or positions. Very few ordinary judges managed to get gifts of any sort for the leaner times. ${ }^{59}$

Many perceived that religious education was the only available channel for their upward mobility. The peasantry responded to this perception by continuing to leave rural areas to come to the religious schools. Once educated, these

54 Inalckk certainly presents it as an Ottoman state response to the crisis of overcrowding (1988:257).

55 Uzunçarsili (1984:94-95).

56 To give an example, the word for dismissal, azl, was used in both sets of registers. Furthermore, the term, dirlik, which was typically used for timar assignments and referred to livelihood on the land, was also used for the allowances especially made to the higher ranking ulema.

57 Quoted in Inalcik (1988:261). $\quad{ }^{58}$ Ibid. $\quad{ }^{59}$ Zilfi (1976:56-57). 
candidates embarked on various hardships during long periods of waiting for a post. The pressure for jobs from these men forced the bureaucracy to reconsider its rule of tenure, shortening them with each crisis. The central government gave great importance to employment as a source of peace and security in the empire. Central officials believed that the potential disruption caused by unemployment could lower significantly the legitimacy and therefore power of the state.

Yet the state was not in total control of this religio-legal administrative institution. At the highest levels, the state entitled every level to nominate and present candidates for positions, thereby allowing them to build their own patronage networks. At the lowest level, the local magistrates could farm their position to deputies but were prevented from forming patronage ties among the peasantry. Consequently, by the eighteenth century, great ulema families had emerged and had gone a long way in determining mobility in the ulema class. 60

Different crisis management techniques were chosen to deal with different levels of the ilmiye. At the highest levels of the hierarchy, overcrowding was dealt with by adding positions and by bringing additional cities to the status requiring notable officials. The state also tried "intersecting actual posts with honorary ranks" 61 as a way of providing more for each appointment. But by far the most important solution was to shorten tenure through the rotation system. For the lower ranks, offices were partitioned by creating new administrative districts as tenure was reduced. ${ }^{62}$

While the creation of new offices mostly redrew administrative lines, rotation in and out of office altered provincial structures even more. The local magistrate became yet another rotating official with whom the rural or the urban constituent could establish only restricted contacts. Judges, as members of the provincial administration, yet independent from the provincial military order, were key figures in the provincial order. As intermediaries in the local structure, they resolved conflicts between local officials and the peasantry and thus had the structural potential of becoming the trusted allies of peasants. But they did not remain in one place long enough to nurture such ties.

Rotation as it applied to judges had a detrimental effect on both the judges and their constituencies. Not only were they unable to form long lasting alliances with judges, but peasants were also exploited by these men who were potentially their closest allies. Judges who held their positions for a specified period of tenure were taken off the payroll when they lost office, before reentering the system. The period out of office varied over time. This period (mulazemet) was justified as providing an opportunity for the judge to work with his mentor and increase his knowledge in order to qualify for a better position. Oversight was ensured by the master being required to file a

60 Ibid., 42. ${ }^{61}$ Ibid., 135-6. 62 Inalcik (1988:261-5). 
report in which he attested to the enhanced qualifications of the judge. ${ }^{63}$ Once more then, rotation was given a meritocratic guise to make it palatable to those who endured its hardships. In reality, when the judge relocated, he was unable to draw income in the form of court dues for the period of rotation. The lifestyle and the requirements of ceremonial attendance in Istanbul made this period quite costly. Quite aware of these hardships at the lower ranks, the central government, careful not to force the highest ranking ulema into the same situation, provided them with allowances.

Judicial membership was ordered in time, with periods in and out of office affecting the livelihood of the members. In order to make financial survival possible, ordinary judges resorted to bribery, exploitation, and the manipulation of the rural population to gain extra income before they went on rotation. As Inalcik explains: "The cadis' rapaciousness became proverbial. Evliya Çelebi, with candor or sarcasm, mentions that such and such a cadiship brought an annual revenue so much 'in justice' but twice as much 'in injustice' as if this were quite a routine case."64 Mustafa Ali, the bureaucrat and historian of the sixteenth century wrote similarly that the judges were "famed for corruption and cupidity, accustomed as they were to receiving fees for their services." 65 Such corruption and exploitation, encouraged by rotation out of paying office, roused local animosity and reduced the likelihood of any potentially rebellious alliance between judges and locals.

\section{Bandit-Mercenaries and Scheduling}

Bandit-mercenary scheduling represented a different form of control. By the mid-sixteenth century, temporal arrangements for office holding had become so routinized that establishing schedules had become perfunctory behavior for the Ottoman state. The hiring and firing of mercenaries was not new: It had been carried out widely in Europe. Yet the practice was an important departure from the traditional military order of the Ottomans. The imposition of a rhythm of making war and the incorporation of bandit-mercenaries through deals with specific time limits increased state control and helped state makers to consolidate and centralize further.

By 1600 in the Ottoman Empire, banditry had become a widespread phenomenon. Bandits were drawn from a continuous supply of vagrant peasants, rebellious student ulema, unruly members of official retinues, and defiant or mutinous soldiers. Each of these groups turned to banditry in response to state action. The sultan and members of the imperial council were intimately and consistently involved in shaping these changes. For all intents and purposes, the state invented and manufactured banditry, disposing of it when it was no longer useful. 66

There is no doubt that the schedule of confronting, bargaining with, or using bandits was not the same as that of the regular bureaucratic state offi-

${ }^{63}$ Ibid. ${ }^{64}$ Ibid., 266. ${ }^{65}$ Fleischer (1986:202). 66 Barkey (1994). 
cials. The schedule was much more irregular, based on the immediate war making and centralizing needs of state makers, and therefore, always remaining subject to change. Unlike the temporal dimension of office holding for the tımar holders and the ulema, these practices for bandits did not get institutionalized. They were not maintained in every part of the empire where bandits roamed. Deals were carried out during a finite period of time, roughly from the late 1550 s to the late $1660 \mathrm{~s}$. This was not true for the other groups. Timar holders and ulema were rotated as long as the institutions existed, and rotation was applied to all regions where tımar holders lived. The state's mercenary schedules and bargains existed primarily for Anatolia, where the major pools of mercenaries were in constant flux and transit. The Balkans and faraway Arab provinces entered the scene only when some of the bandit chiefs accepted postings in far-flung areas of the empire. Otherwise, especially during this period, wars with Persia located bandit and mercenary activity in central and eastern Anatolia.

While these differences existed, in many ways the crises that triggered the scheduling of office for land holders and magistrates were comparable to those of the mercenary-bandits. The crises of overcrowding applied to all three groups: While the first two suffered from too many men for the available positions, the third group was in part the result of overcrowding on the land. Pushed off the land, men became mercenaries, bandits, or both. State hiring of mercenaries further pushed men from the land. Timar holders were also state-made forces, similar to mercenaries, for members of both groups directed their demands toward, and acquired their rewards from, the state. Timar holders were servants of the state; Bandits aspired to become so.

The pattern of the state using mercenaries and of dealing with them as bandits took new forms with changes in military technology. In the seventeenth century, local militarization, triggered and maintained by the centralizing needs of the state, became the most significant transformation in the countryside. Because the requirements of international warfare had changed, the state needed an army bearing muskets in lieu of the traditional cavalry riding horses. The Ottoman state started responding to the developments in European infantry early on during the reign of Süleyman I (1520-66), increasing the size of Ottoman infantry forces as well as speeding the production of firearms. ${ }^{67}$ Despite these attempts, Ottoman armies were not really ready for this new type of confrontation. This was demonstrated by their problems with the Habsburgs during the war lasting from 1593 to 1606, especially when facing Prince Mihal of Wallachia and his infantry corps.

A renewed effort toward firearms resulted in much more serious militarization. The state and military elites were reluctant to transform existing forces into armies bearing muskets. These elites turned to the countryside. By draw- 
ing from provincial retinues or by direct military conscription, the state gained the manpower it needed for its own expansion and centralization, while vagrants and retinue members gained employment. Peasants who had previously been carefully kept out of the military were now lured by provincial officials to join their retinues or were directly enlisted into the sultan's army. Provincial officials were forced to enlarge their retinues since they competed for state privileges. The availability of firearms in the countryside facilitated this move away from the land into military pursuits. As a result, the state became a significant client for mercenaries organized around units ready for hire. ${ }^{68}$

Whether in war or peace, the state controlled the movement of mercenaries in and out of pools. When the state's needs soared during periods of war, it entered into contracts with mercenaries, who imitated official military formats and had their units duplicate army organization and leadership. During wartime, the state provided for the mercenaries, hiring, arming, clothing, organizing, and paying them a daily wage while exempting them from taxation. 69 Peacetime required a rotation out of arms, which, like other more bureaucraticized rotations in the empire, imposed hardships on the affected population. As soon as the mercenaries' campaigns were over and their military standards were taken away, they were demobilized en masse and left to their own devices for an unspecified period of time. The schedule of rotation in this case was more variable, yet very well understood. Mercenaries simply engaged in banditry while they were waiting for another campaign to fight in. And when under conditions of demilitarization, they effectively became bandits, whose chiefs, former mercenary leaders, now supervised organized looting.

Making deals with bandits functioned as a form of irregular control over a territory. During the seventeenth century the Ottoman state made ample use of political deal making and co-optation for a long time as a way of incorporating the claims of bandit chiefs at the helm of large mercenary troops. As aspiring elites, bandit leaders demanded state positions and incorporation into the Ottoman bureaucracy. In the bargains which followed, bandit chiefs were often made governors in return for committing their mercenary-bandit troops to war. The annals of the eastern campaigns of the end of the sixteenth and the beginning of the seventeenth centuries are replete with such maneuvers on the part of wily grand viziers. In one instance, the powerful and notorious bandit chieftain, Canboladoglu Ali Pasha, promised more than 16,000 men to fight the upcoming wars on the eastern front and demanded fourteen high-level administrative positions in the east for himself and a variety of his regional officials. ${ }^{70}$ While bandits may have perceived their position as permanent, this was certainly not the case. Grand viziers on campaign used the mercenaries and overlooked temporary abuses by a new governor while waiting for

68 Inalcik (1980:283-337). ${ }^{69}$ Inalcik (1980). 70 Barkey (1994) and Griswold (1983). 
the campaign to be over in order to remove the governor from his position. The removal was often executed swiftly by way of an internal campaign that destroyed the bandit retinue.

With bandits, then, two different types of schedules worked. When they were simple mercenaries, they rotated in and out of war. When they became more organized around leaders, bargains and pretense worked to provide perceptions of office holding. Deal making and incorporation occurred along temporal dimensions, demonstrating a need for the state to schedule demands, interests, and actors. Periods of state rule which made use of rotation or made concessions to bandits were not periods of weakness signaling an empire about to collapse. These were rather calculated deals made to balance international and internal pressures so that the Ottomans did not have to simultaneously confront warfare on three fronts: European, Eastern, and Anatolian. Therefore, geopolitical considerations inspired deal making and scheduling.

\section{CONCLUSION}

The Ottoman state established control over a vast empire. Such control required the scheduling of state interactions both with the regular administrative staff and potential enemies with whom the state bargained. In that sense, time as a social construct helped the state order its relations with the different elements of society. Rotation instituted as a response to the short-term crises of overcrowding became a significant basis of control. As an unintended consequence of its style of crisis-management, the Ottoman state kept the essence of the patrimonial household alive for longer than many other such polities. The household persuaded its loyal and disloyal members that rewards and mobility could be won only through the state. Rotation served to reinforce this centralization, since disjointed and competing elites had to wait for those times when the state provided.

The Ottoman state, created with multiple groups through multiple times, regulated society. Each group acquired its own time and lived by the rules of its particular schedule. Membership in official orders took place in time. Rewards depended on whether members were in or out of rotation. The provincial military moved according to schedules of war and rotation. They went on campaigns and on rotation, sometimes willingly, sometimes by force. Strong networks of comradeship were continually disrupted. The vast number of judges who criss-crossed the realm of the sultan moved according to schedules of rotation, retraining themselves and then waiting for another posting to be granted. Such instability vitiated any possible local alliances.

Even at the top levels, rotation was common. Time was a resource over which serious bargaining occurred. Both governors and high-ranking ulema were recognized as men of valor, and their hardships were relieved with intermittent state largess offered in lieu of office. Powerful landed aristocrats bargained for their tenure as their major resource, acquiring some privileges. 
The great mollas were rotated, though they attempted to offset such instability by reinforcing family ties and mobility. Also, at this level, governors and ulema distributed their wealth rather freely in order to assemble loyal clients. ${ }^{71}$ Therefore, while the state structured social relations around time, creating "socially expected durations," some elites were able to tamper with these orderings.

While the wealthy top-ranking elites were able to gather retinues and clients despite rotation, the majority of elites were not so lucky. Rotation insured that officials would not ensconce themselves in the provinces, join with other officials, acquire clients, and conspire against the state. While the peasant remained in one place, his multiple patrons came and went, each following the rhythm of his profession. The third group, bandit-mercenaries played havoc with all these arrangements when not reined in by the state. The ordering of provincial relations during this period of Ottoman history depended on the state's ability to bargain effectively with and rotate bandits. Thus, a threat to the existing orders was contained by creating yet another order of rotation.

These processes fit with a more general cultural understanding of the role of the imperial state which emerged out of the notion of the "Circle of Justice." As an extension of this vision, different classes in society, the military, the men of learning, the merchants and artisans, and the peasants represented different pillars of society which were to be kept separate. ${ }^{72}$ This separation of spheres was applied to most societal institutions. The millet system-the administration of non-Muslim religious communities-as well as the guild system are other examples of such separation. As has been argued in other contexts, it is therefore quite premature to discuss the existence of a civil society in the Ottoman Empire of this period. Kasaba demonstrates how this more state-controlled separation of spheres and lack of networking began to change during the nineteenth century. Especially under conditions of increased contact with the world economy, the economic organization of the empire changed, stimulating movement, networking, and association. ${ }^{73}$ The development of this non-state arena altered the organization of control, leading the way to other modes and adaptations.

Two sets of comparisons further illuminate the relationship between state control and scheduling of office. A comparison across time with the late seventeenth century and early eighteenth century can illuminate why an apparently successful policy of rotation for provincial land tenure was abandoned. Another comparison across groups, with the magistrates who continued to flourish and keep their provincial administrative functions, will also reinforce this argument.

71 Evliya Çelebi provides numerous examples of gifts between patrons and clients in his Book of Travels (see Dankoff [1991]).

72 Inalcik (1992). ${ }_{73}$ Kasaba (1994). 
If it got the Ottoman state control, why was rotation relinquished in the late seventeenth century? After the final reorganization of the land tenure system during the reign of Murad IV (1623-40), the tımar was abandoned. Large land holders remained on their land, successfully fending off rivals, whereas the small land holders dropped out of the system. The declining significance of the tımar was due to the need for Ottomans to fight using firearms. Technological changes outside Ottoman control had forced the military format to change, sending the state on the road towards new modes of adaptation. The reorganization of Murad IV facilitated this adaptation, consolidating only institutional fragments of interest to the state. When the timar organization faded, its major characteristics disappeared with it. Since most of the other tasks that the timar holders performed had still to be fulfilled, other members of the rural arrangements were pulled into duty. A quick survey into the late seventeenth and early eighteenth centuries shows that new relations between center and periphery were developed to attempt to bind the provincial groups to those in power at the center. The failure of old ways furnished new opportunities for new means of control. Thus, the Ottoman use of time for social control was itself bounded by time.

Among those who were pulled into heavier responsibility were the ordinary judges who canvassed the Ottoman realm. The ilmiye therefore not only remained untouched by such exogenous change but also stood to gain from the demise of the timar holders. For these magistrates, rotation for all ranks remained functional well into the nineteenth century. Even though great molla families became powerful enough to influence mobility internal to the ilmiye, the movement by which they remained servants of the state continued. Hence, we understand that it was not immediately in the state's interest to stop rotation. Where there was no crisis, rotation continued; and those who were rotated found ways to adapt to this rotational lifestyle. We can conclude that, despite similar origins in the crisis of overcrowding of office, different rotations of different groups served varied purposes. They were perceived as separate and were made to experience distinct fates according to state needs.

Rotation ordered, but reversing rotation also served as a tool for bargaining and thereby increasing power. The temporal dimension of rule in many ways allowed for more flexibility in negotiation. Between permanency and three years in office, many agreements could be made. And when rotation was not a viable alternative, deal making was used as a way of scheduling, as it was with bandits. In this sense, unevenness and irregularity became a mechanism for increased power. For every trend which established a rule of control, some strategy situated an undertow of compromise.

\section{REFERENCES}

Aminzade, Ronald. 1992. "Historical Sociology and Time." Sociological Methods and Research, 20 (May), 456-480. 
Andric, Ivo. 1992. "The Vezir's Elephant." in The Damned Yard and Other Stories. Boston: Forest Books.

Barkey, Karen. 1991a. "Rebellious Alliances: The State and Peasant Unrest in Early 17th Century France and the Ottoman Empire." American Sociological Review, 56 (December), 699-715.

1991b. "The Uses of Court Records in the Reconstruction of Village Networks: A Comparative Perspective." International Journal of Comparative Sociology, 32:1-2, 196-216.

1994. Bandits and Bureaucrats: The Ottoman Route to State Centralization. Ithaca: Cornell University Press.

Beldiceanu-Steinherr, Irène. 1979. "Loi sur la transmission du tımar (1536)." Turcica, no. 9 (1979), 78-102.

Bourdieu, Pierre. 1963. "Time Perspectives of the Kabyles." Mediterranean Countryman, 6, 55-72.

1977. Outline of a Theory of Practice, Richard Nice, trans. Cambridge, Eng.: Cambridge University Press.

Brustein, W; and Margaret Levi. 1987. "The Geography of Rebellion: Rulers, Rebels, and Regions, 1500 to 1700." Theory and Society, 16:4, 467-95.

Brustein, William. 1985. "Class Conflict and Class Collaboration in Regional Rebellions, 1500-1700." Theory and Society, 14:4, 445-68.

Bulliet, Richard W. 1972. The Patricians of Nishapur: A Study in Medieval Islamic Social History. Cambridge, Mass: Harvard University Press.

Carruthers, Bruce; Terence Halliday. 1992. "Politics and Temporality: Agenda-Setting in U.S. and English Bankruptcy Law." Unpublished paper.

Dankoff, Robert, trans. and comm. 1991. The Intimate Life of an Ottoman Statesman, Melek Ahmed Pasa (1588-1662). Albany, NY: State University of New York Press.

Findley, Carter. 1980. Bureaucratic Reform in the Ottoman Empire: The Sublime Porte, 1789-1922. Princeton: Princeton University Press.

Fleischer, Cornell. 1986. Bureaucrat and Intellectual in the Ottoman Empire: The Historian Mustafa Ali (1541-1600). Princeton: Princeton University Press.

Griswold, William J. 1983. The Great Anatolian Rebellions, 1000-1020/1591-1611. Berlin: Klaus Schwarz Verlag.

Howard, Douglas. 1987. "The Ottoman Timar System and its Transformation, 15631656." Bloomington, IN: Ph.D. disser., History Department, Indiana University.

Inalck, Halil. 1954a. "Ottoman Methods of Conquest." Studia Islamica, no. 3:103129.

-. 1954b. Hicri 835 Tarihli Suret-i Defter-i Sancak-i Arvanid. Ankara: Türk Tarih Kurumu.

- 1973. The Ottoman Empire: The Classical Age, 1300-1600. New York: Weidenfeld and Nicolson.

. 1975. "The Socio-Political Effects of the Diffusion of Firearms in the Middle East," in War, Technology and Society in the Middle East, V. J. Parry and M. E. Yapp, eds. Oxford: Oxford University Press.

- 1977. "Centralization and Decentralization in Ottoman Administration," in Studies in Eighteenth Century Islamic History, Thomas Naff and Roger Owen, eds. Carbondale, Ill.: Southern Illinois University Press.

. 1980. "Military and Fiscal Transformation in the Ottoman Empire, 16001700." Archivum Ottomanicum, no. 6, 283-337.

-1988. "The Ruznamce Registers of the Kadıasker of Rumeli as Preserved in the Istanbul Müftülük Archives." Turcica, no. 20, 251-75. 
1992. The Middle East and the Balkans under the Ottoman Empire: Essays on Economy and Society. Bloomington, IN: Indiana University Press.

. 1995. Economic and Social History of the Ottoman Empire, 1300-1914. Cambridge, Eng.: Cambridge University Press.

Jennings, Ronald C., 1972. "The Judicial Registers ("Ser'i Mahkeme Sicilleri") of Kayseri (1590-1630) as a Source for Ottoman History." Los Angeles: Ph.D. disser., History Department, University of California, Los Angeles.

Kasaba, Resat. 1994. "A Time and a Place for the Nonstate: Social Change in the Ottoman Empire during the 'Long Nineteenth Century,'" in State Power and Social Forces: Domination and Transformation in the Third World, Joel S. Migdal, Atul Kohli, and Vivienne Shue, eds. Cambridge, Eng: Cambridge University Press.

Koçi Bey. 1972. Risale, Zuhuri Danisman, ed. Istanbul: Milli Egitim Basimevi.

Kunt, Metin. 1983. The Sultan's Servants: The Transformation of Ottoman Provincial Government, 1550-1650. New York: Columbia University Press.

Lapidus, Ira M. 1988. A History of Islamic Societies. Cambridge, Eng.: Cambridge University Press.

Lukes, Steven. 1974. Power: A Radical View. London: Macmillan.

Merton, Robert K. 1984. "Socially Expected Durations: A Case Study of Concept Formation in Sociology," in Conflict and Consensus: A Festchrift in Honor to Lewis A. Coser, Walter W. Powell and Richard Robbins, eds. New York: The Free Press.

Murphey, Rhoads. 1979. "The Veliyyuddin Telhis: Notes on the Sources and Interrelations Between Koçi Bey and Contemporary Writers of Advice to Kings." Belleten, 43:17 (1979), 547-571.

Pocock, J.G.A. 1971. Politics, Language and Time: Essays on Political Thought and History. New York: Atheneum.

Rudolph, Susanne. 1987. "Presidential Address: State Formation in AsiaProlegomenon to a Comparative Study." The Journal of Asian Studies, 46:4, 73146.

Thompson, E. P. 1967. "Time, Work-Discipline, and Industrial Capitalism." Past and Present, 38:56-97.

Tilly, Charles. 1993. "The Time of States." The Working Paper Series, Center Studies of Social Change, New School for Social Research, October 1-17.

Uzunçarsılı, Ismail Hakkı. 1984. Osmanlı Devletinin Ilmiye Teskilatı. Ankara: Türk Tarih Kurumu Basımevi.

Yücel, Yasar. 1974. "Osmanlı Imparatorlugunda Desentralizasyona dair Genel Gozlemler." Belleten, 38:152, 657-708.

Weber, Max. 1978. Economy and Society, Guenther Roth and Claus Wittich, eds. Berkeley: University of California.

White, Harrison. 1970. Chains of Opportunity: System Models of Mobility in Organizations. Cambridge, MA: Harvard University Press.

1992. Identity and Control. Princeton: Princeton University Press.

Winship, Christopher. 1992. "Social Relations and Time." Unpublished paper.

Zerubavel, Eviatar. 1981. Hidden Rhythms. Berkeley: University of California Press.

Zilfi, Madeline. 1976. "The Ottoman Ulema 1703-1839 and the Route to Great Mollaship." Chicago: Ph.D. disser., History Department, University of Chicago.

- 1983. "Elite Circulation in the Ottoman Empire: Great Mollas of the Eighteenth Century." Journal of the Economic and Social History of the Orient, 26:3, $318-364$.

-1988. The Politics of Piety: The Ottoman Ulema in the Post-Classical Age (1600-1800). Minneapolis: Bibliotheca Islamica. 